\title{
Jatkuvatoiminen leväpitoisuuden mittaus kosteikkovedestä
}

\author{
Tiina Siimekselä \\ Jyväskylän ammattikorkeakoulu, Biotalousinstituutti, Tuumalantie 17, 43130 Tarvaala \\ tiina.siimeksela@jamk.fi
}

Jatkuvatoimista levien määrän mittausta voidaan hyödyntää vesistöseurannassa ja sen avulla voidaan havaita esimerkiksi sinilevien lisääntyminen vaikkapa uimarannalla jo ennen kuin leväkasvusto on paljain silmin havaittavissa. Levien määrän jatkuvatoimista mittaamista tutkittiin Tarvaalan Biotalouskampuksen pohjoisella mallikosteikolla kesällä 2016. Tutkimuksen tavoite oli selvittää, voidaanko kosteikkoveden leväpitoisuutta ja sen vaihtelua seurata jatkuvatoimisesti, sekä edistää levänkasvatusmenetelmän kehittämistä luonnollisten leväkantojen hallittuun kasvattamiseen maatalouden vesiensuojelukosteikolla selvittämällä levien kasvuun vaikuttavia tekijöitä. Tutkimus oli osa BioA- Biojalostamokonseptin tuotteistamisesta liiketoimintaa -hanketta.

Jatkuvatoimisen mittauksen luotettavuutta selvitettiin vertaamalla EXO2 In Situ Total Algae automaattisen mittausanturin a-klorofyllimittaustuloksia laboratoriossa määritettyihin vesinäytteiden tuloksiin. Tutkimus toteutettiin 19.5.-29.8.2016 (103 vuorokautta). Tutkimusaineisto kerättiin kahdella maatalouden vesiensuojelukosteikon tulouomaan asennetulla automaattisella In Situ mittausanturilla, joiden mittaustaajuus oli kerran tunnissa. Mittauskohteesta otettiin 15 yksittäistä vesinäytettä, joista seitsemästä näytteestä analysoitiin laboratoriossa a-klorofyllipitoisuus ja kahdeksasta näytteestä sameus sekä kiintoaineen, kokonais- ja nitraattitypen, kokonaisfosforin ja liukoisen orgaanisen hiilen pitoisuudet.

Tutkimuksessa havaittiin, että automaattiantureiden mittaamat tulokset vastasivat hyvin laboratoriossa määritettyjä tuloksia. Kosteikkovedessä mitattiin varsin korkeita leväpitoisuuksia noin kahden viikon ajan kesäkuun puolen välin tienoilla samaan aikaan veden fosforipitoisuuden nousun kanssa. Veden ravinnepitoisuuksien vaihtelun ja levämäärän välillä ei kuitenkaan havaittu tilastollisesti merkitsevää yhteyttä. Myöskään veden lämpötilan tai sääolosuhteiden vaihtelulla ei tässä tutkimuksessa havaittu olleen vaikutusta leväpitoisuuteen. Tulokset saattavat johtua mittauspaikalle kasvaneesta poikkeuksellisen runsaasta vesikasvillisuudesta, joka heikensi levien kasvua kilpailemalla samoista ravinteista sekä varjostamalla leviä.

Tutkimusjakson tulosten perusteella kosteikkoveden leväpitoisuutta ja sen vaihtelua voidaan mitata luotettavasti jatkuvatoimisella a-klorofyllin ja fykosyaniinin fluoresenssin mittauslaitteistolla. Tutkimuksessa saatujen tulosten perusteella jatkuvatoimisella mittauksella voidaan havaita esimerkiksi sääilmiöiden aiheuttamat nopeat pitoisuuksien muutokset, jotka yksittäisiin vesinäytteisiin perustuvassa seurannassa jäävät usein huomaamatta.

Tutkimus tehtiin Jyväskylän ammattikorkeakoulun agrologi (ylempi AMK) -opinnäytetyönä.

Asiasanat: fluoresenssi, a-klorofylli, jatkuvatoiminen levämäärän mittaus, kosteikko 


\section{Johdanto}

Suomen matalat ja pinta-alaansa nähden vesimassaltaan pienet vesistöt ovat herkkiä ulkoiselle kuormitukselle. Rehevöityminen on Suomen vesistöjen laaja-alaisin ongelma, josta usein ensimmäisenä kertovat tavanomaisesta poikkeavat levien massaesiintymät. Kasviplankton onkin yksi keskeisistä laatutekijöistä vesistöjen ekologisen tilan ja käyttökelpoisuuden arvioinnissa. Kasviplanktonin määrässä ja lajistossa tapahtuvat muutokset ilmentävät esimerkiksi veden laadun fysikaalisia ja kemiallisia muutoksia melko luotettavasti. Jatkuvatoimisella a-klorofyllin ja muiden levien yhteyttämispigmenttien mittauksella voidaan saada yksittäisiä lähes reaaliaikaista tietoa kasviplanktonin määrän ja lajiston nopeastakin vaihtelusta ja näin vesistöjen tilaan vaikuttavista muuttujista esimerkiksi vesistökuormituksen hallinnan tueksi

Suurin osa vesistöjen typpi- ja fosforikuormituksesta on peräisin maataloudesta, jossa ravinnehuuhtoumia on pyritty vähentämään esimerkiksi perustamalla vesiensuojelukosteikkoja pidättämään pelloilta tulevien valumavesien ravinteita. Kosteikkojen ravinteita pidättävä vaikutus perustuu nykytiedon mukaan pitkälti siellä kasvavan kasvillisuuden ravinteiden käyttöön. Kosteikkojen kasviplanktonia, eli lähinnä leviä ja syanobakteereita, ja sen vaikutusta kosteikon ravinteidenpidätyskykyyn ei ole juurikaan tutkittu.

Tämän tutkimuksen tavoitteena oli selvittää, voiko kosteikkoveden leväpitoisuutta ja sen vaihtelua seurata jatkuvatoimisesti. Lisäksi tutkittiin veden ravinteiden ja lämpötilan vaihtelun sekä sääoloissa tapahtuvien muutosten vaikutusta levien määrään tutkimuskohteella. Tutkimus oli osa EU:n aluekehitysrahaston rahoittamaa BioA-hanketta, jonka yhtenä tavoitteena oli kehittää menetelmä luonnollisten leväkantojen hallittuun kasvattamiseen luonnon olosuhteissa maatalouden vesiensuojelukosteikolla.

\section{Aineisto ja menetelmät}

\section{Tutkimusalue}

Tutkimus toteutettiin Keski-Suomessa Saarijärvellä Tarvaalan Biotalouskampuksen pohjoisella kosteikolla (Kuva 1), joka sijaitsee Summanen-järven rannalla. Summanen on osa maisemallisesti arvokasta Saarijärven vesireittiä. Natura 2000-verkostoon kuuluvan Saarijärven vesireitin vedet ovat karuja ja humuspitoisia. Suurin osa Keski-Suomen alueen tyydyttävän tai sitä huonomman ekologisen luokituksen saaneista vesistöistä sijaitsee Saarijärven reitillä, jonka järvistä lähes $60 \%$ on ekologiselta tilaltaan tyydyttävässä tai sitä huonommassa tilassa pääasiassa hajakuormituksen aiheuttaman rehevöitymisen vuoksi.

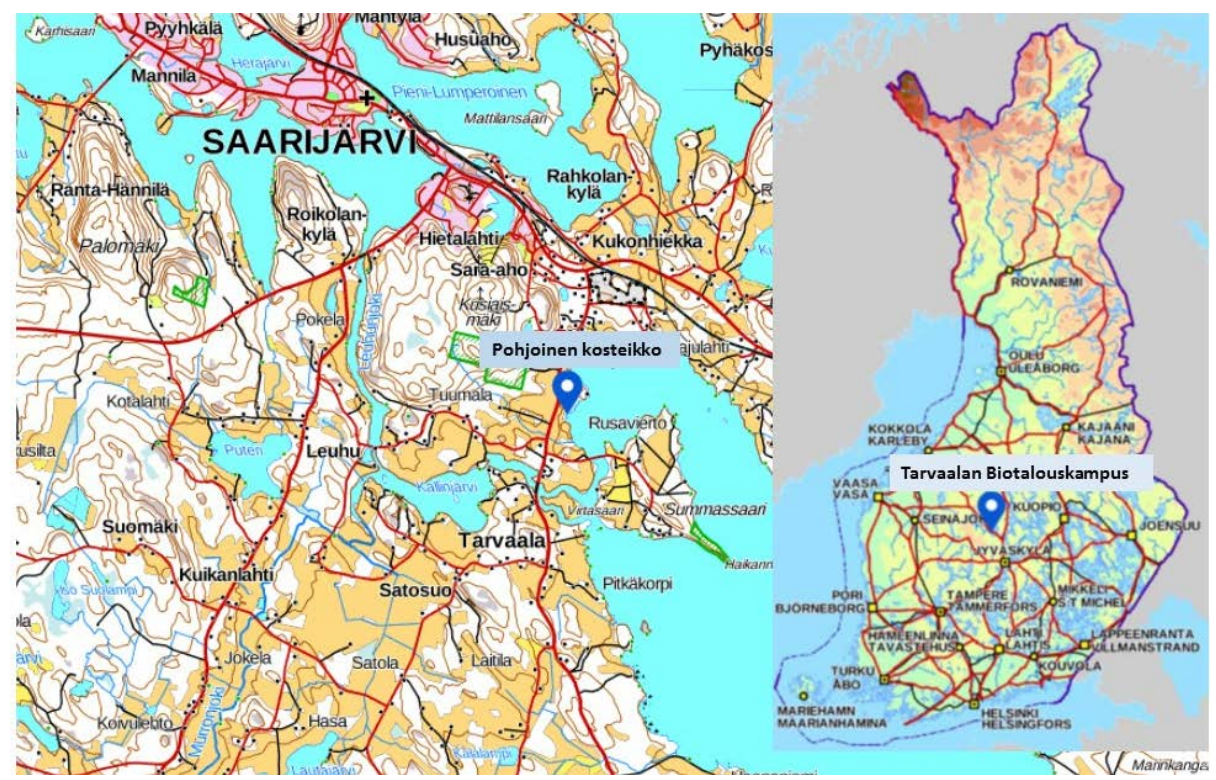

Kuva 1. Tutkimusalueen sijainti (Tulostettu Maanmittauslaitoksen asiointipalvelusta, muokattu) 
Pohjoinen kosteikko on pinta-alaltaan 1,34 ha, mikä on 4,6\% sen 29 hehtaarin kokoisesta valuma-alueesta. Valuma-alueesta noin puolet on maatalousmaata, joka tutkimusjaksolla oli kokonaan nurmiviljelyssä. Pohjoisen kosteikon valuma-alueen vallitsevat maalajit ovat metsäalueiden hiekkamoreeni ja peltojen hiesu.

\section{Tutkimusajanjakso}

Tutkimus toteutettiin 19.5.-29.8.2016. Tutkimusjakson pituudeksi tuli näin ollen 103 vuorokautta. Tutkimusajankohta määräytyi aikaisempina vuosina tehtyjen maastohavaintojen perusteella, joiden mukaan veden pinnalla on havaittu näkyvää leväkasvustoa toukokuun alusta - toukokuun puolesta välistä elokuun puoliväliin - elokuun loppuun.

Tutkimuskuukausien lämpötilat vastasivat heinä- ja elokuun osalta täysin Ilmatieteen laitoksen pitkäaikaista keskiarvoa ilmastollisella vertailukaudella 1981-2010. Toukokuussa keskilämpötila oli hieman alle neljä astetta 4 ja kesäkuussa noin asteen tavanomaista lämpimämpi. Koko tutkimusjakson keskilämpötila oli asteen Ilmatieteen laitoksen pitkäaikaista keskiarvoa korkeampi.

Toukokuun sademäärä jäi alle puoleen Ilmatieteen laitoksen pitkäaikaisesta keskiarvosta kesäkuun sademäärän ollessa hyvin lähellä ajankohdan tavanomaista sademäärää. Heinä- ja elokuussa satoi 25-30 mm tavanomaista enemmän, mutta koko tutkimusjakson aikainen sadesumma oli lähellä Ilmatieteen laitoksen mukaista alueen pitkäaikaista vastaavan ajankohdan sademäärää.

Tutkimusjakson suurimmat sateet mitattiin Tarvaalan Biotalousinstituutin sääasemalla 4. ja 5.7. (70 mm). Heinäkuu myös jatkui sateisena aina kuun puoliväliin saakka. Suurimmat vedenpinnankorkeudet tutkimuskohteessa mitattiin kuitenkin vasta sadejakson päättymisen jälkeen 17.-30.7., sekä tutkimusjakson alussa toukokuun puolessa välissä olleiden sadepäivien jälkeen. Tutkimusjakson vuorokautiset sadesummat (mm) ja ilman keskilämpötila $\left({ }^{\circ} \mathrm{C}\right)$ Tarvaalan Biotalousinstituutin sääasemalla mitattuna sekä veden pinnankorkeus mittauskohteessa $(\mathrm{cm})$ on esitetty Kuvassa 2.

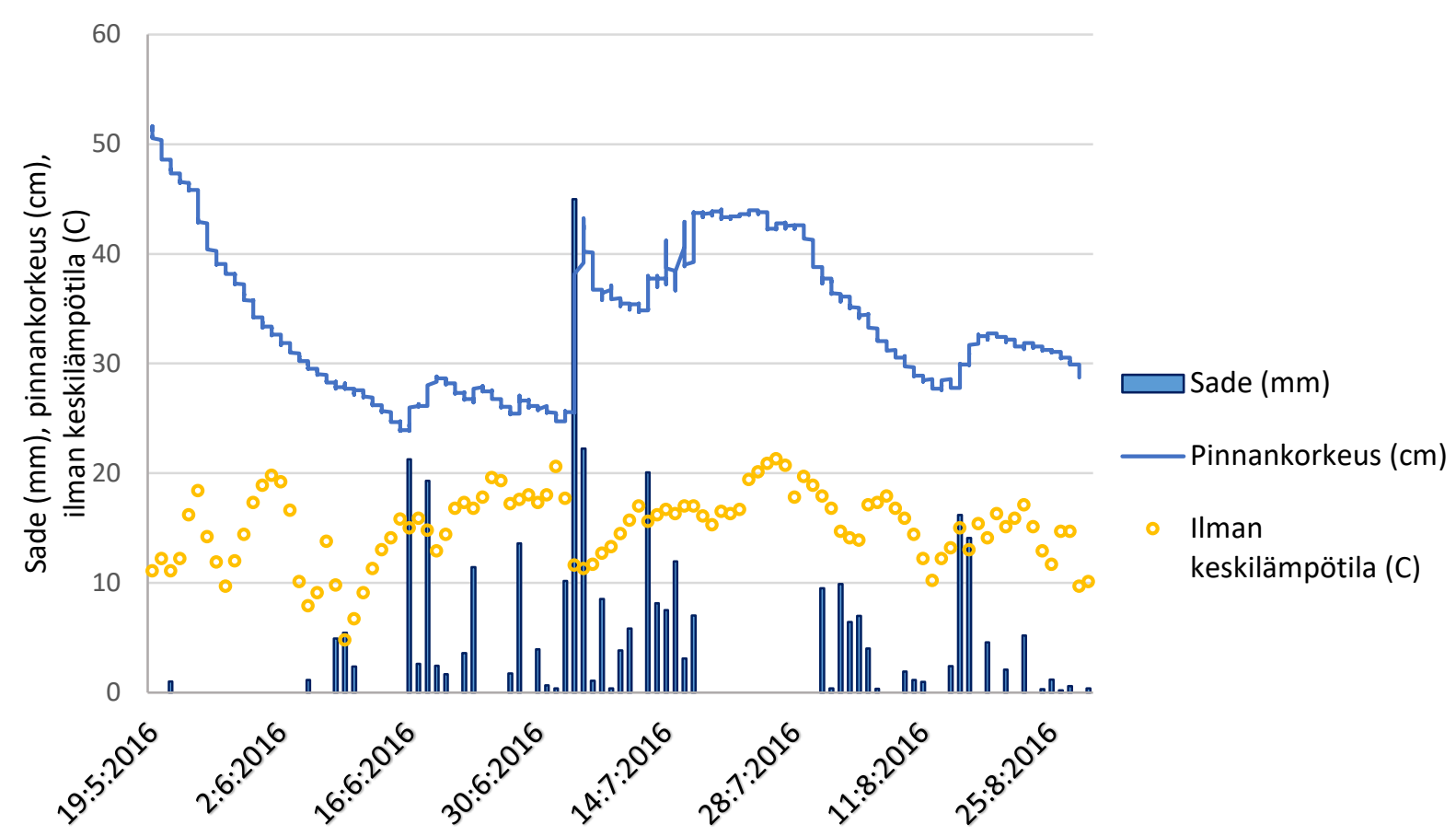

Kuva 2. Vuorokautinen sadesumma (mm) ja ilman keskilämpötila $\left({ }^{\circ} \mathrm{C}\right)$ Tarvaalan Biotalousinstituutin sääasemalla mitattuna sekä mittauskohteen vedenpinnankorkeus (cm) tutkimusjaksolla 19.5.-29.8.2016 


\section{Aineiston kerääminen}

Kosteikolle tulevan veden leväpitoisuutta kuvaavaa a-klorofyllin ja fykosyaniinin määrää mitattiin EXO2-mittaussondin Total Algae -yhdistelmäanturilla. Yhdistelmäanturi valittiin, koska mikroskooppitarkastelun (Jyväskylän yliopisto Kristiina Vuorio) perusteella tutkimuskohteen leväyhteisössä tiedettiin olevan myös sinileviä. Mittaussondissa oli tutkimusjaksolla a-klorofylli- (viritys $\lambda 470 \pm 15 \mathrm{~nm}$, emissio $\lambda 685 \pm 20 \mathrm{~nm}$ ) ja fykosyaniiniantureiden (viritys $\lambda 590 \pm 15 \mathrm{~nm}$, emissio $\lambda 685 \pm 20 \mathrm{~nm}$ ) lisäksi veden lämpötilaa $\left({ }^{\circ} \mathrm{C}\right)$, johtokykyä $\left(\mu \mathrm{S} \mathrm{cm}{ }^{-1}\right.$, fluoresenssia (fDOM) ja sameutta (FTU) mittaavat anturit sekä pinnankorkeusanturi (cm).

Veden ravinnepitoisuuksien vaihtelun vaikutus levämäärään tahdottiin selvittää, joten kosteikolle tulevasta vedestä mitattiin optisesti sameutta (FTU) ja nitraattitypen $\left(\mathrm{NO}_{3}-\mathrm{N}\right)$ sekä liukoisen orgaanisen hiilen pitoisuutta (DOC) ravinnepitoisuutta S::can UV-VIS spektrometrillä. Veden kokonaisfosfori- (Ptot) ja kiintoainepitoisuudet laskettiin regressioyhtälön avulla käyttämällä sijaismuuttujana sameutta, jonka on havaittu korreloivan hyvin kiintoainepitoisuuden ja joissakin tapauksissa kokonaisfosforipitoisuuden kanssa. (mm. Valkama ym. 2007, Siimekselä ym. 2011.)

Automaattisten mittausantureiden mittaustaajuus oli kerran tunnissa ja tiedonsiirto tapahtui reaaliaikaisesti GSM-yhteydellä JAMK:n Mango-verkkopalvelimelle. Molemmat mittausanturit puhdistuivat automaattisesti tunnin välein, S::can paineilmalla ja EXO2 harjamenetelmällä. Lisäksi anturit puhdistettiin manuaalisesti kerran viikossa.

Mittauspaikalta otettiin a-klorofyllipitoisuutta mittaavan fluorometrin (EXO2) paikalliskalibrointia ja validointia varten seitsemän vesinäytettä, joista määritettiin laboratoriossa a-klorofyllipitoisuus. S::cananturin paikalliskalibrointia ja validointia varten kahdeksasta vesinäytteestä määritettiin laboratoriossa sameus (FNU) sekä kiintoaine-, kokonaistyppi- (N), nitraattityppi- $\left(\mathrm{NO}_{3}-\mathrm{N}\right)$, kokonaisfosfori- (P) ja liukoisen orgaanisen hiilen (DOC) pitoisuudet.

\section{Tulokset ja tulosten tarkastelu}

\section{Automaattiantureiden toiminta}

Jatkuvatoimisen automaattianturin mittaama, paikalliskalibroitu a-klorofyllipitoisuus vastasi laboratoriossa määritettyä pitoisuutta erinomaisesti selityskertoimen $\left(\mathrm{r}^{2}\right)$ ollessa $0,9995(\mathrm{p}<0,001)$. A-klorofyllianturin paikalliskalibroinnissa käytettiin kahden selittävän muuttujan regressioyhtälöä, jossa selittävinä muuttujina (x) olivat anturin mittaamat a-klorofyllin ja fykosyaniinin pitoisuudet ja selitettävänä (y) muuttujana laboratoriossa vesinäytteistä määritetty a-klofyllin pitoisuus.

Liuenneen orgaanisen aineen määrää kuvaavan fDOM-arvon lisääminen selittäjäksi ei vaikuttanut kalibrointiyhtälön selitysasteeseen, mutta huononsi mallin p-arvoa sekä lisäsi vakiotermin negatiivisuutta. Tulos vastaa Kringin ym. (2014) saamia tuloksia, joissa orgaanisen aineksen määrällä ei ollut vaikutusta a-klorofyllin mittaukseen. Sitä vastoin mm. Kuha (2016) on havainnut orgaanisen aineen aiheuttavan virheitä jatkuvatoimiseen a-klorofyllin mittaukseen humuspitoisissa vesistöissä ja orgaanisen aineen pitoisuuden (esim. fDOM) käytön yhtenä selittäjistä parantavan kalibroinnin laatua ja vähentävän humuksen a-klorofyllimittaukseen aiheuttamaa virhettä.

S::can anturin optisesti mittaamat sameusarvot (FTU) vastasivat erinomaisesti labo-ratoriossa määritettyjä arvoja $\left(\mathrm{r}^{2}=0,99, \mathrm{p}<0,001\right)$. Automaattianturin mittaaman sameuden perusteella laskettu veden kiintoainepitoisuus vastasi laboratoriossa määritettyjä arvoja melko huonosti $\left(r^{2}=0,58, p=0,03\right)$. Niin ikään sameuden perusteella lasketun kokonaisfosforipitoisuuden vastaavuus laboratoriossa määritettyihin arvoihin oli kohtalainen $\left(\mathrm{r}^{2}=0,7, \mathrm{p}<0,01\right)$. Vastaavia tuloksia on saatu aiemminkin saman tyyppisiltä hiesu- ja moreenimailta (mm. Siimekselä ym. 2013, Räty ym. 2014), joissa karkearakeinen kiintoaine ei kulkeudu veden mukana saviaineksen tapaan ja fosfori on pääosin liukoisessa muodossa.

\section{Vedenlaatumuuttujien vaihtelu tutkimusjaksolla}

Tutkimuskohteen veden a-klorofyllipitoisuus vaihteli suuresti tutkimusjakson aikana keskipitoisuuden ollessa $59 \mu \mathrm{g} \mathrm{l}^{-1}$, vaihteluväli < 1-899 $\mu \mathrm{g} \mathrm{l}^{-1}$. Suurimmat pitoisuudet mitattiin kesäkuussa, jolloin aklorofyllipitoisuudessa havaittiin 13 vuorokautta kestänyt piikki (Kuva 3). Tämän jälkeen pitoisuus laski 
nopeasti ja pysytteli kahta pienempää piikkiä (24.6. ja 4.7.) lukuun ottamatta pääosin alle $20 \mu \mathrm{g} \mathrm{l}^{-1}$ tutkimusjakson loppuun saakka.

Kaikki a-klorofyllin pitoisuuspiikit esiintyivät ilman keskilämpötilan $\left({ }^{\circ} \mathrm{C}\right)$ laskiessa lämpimän jakson jälkeen. Ilman lämpötilan ja a-klorofyllipitoisuuden välillä ei kuitenkaan havaittu tilastollisesti merkitsevää riippuvuutta. Myöskään veden lämpötilan $\left({ }^{\circ} \mathrm{C}\right)$, veden pinnankorkeuden $(\mathrm{cm})$ tai vuorokautisen sadesumman $(\mathrm{mm})$ ei havaittu vaikuttavan merkitsevästi a-klorofyllin määrään tutkimuskohteessa. Edellä mainittujen ympäristömuuttujien ja automaattianturin mittaaman veden a-klorofylli-pitoisuuden vaihtelu tutkimusjaksolla sekä laboratoriossa määritetyt a-klorofyllipitoisuudet on esitettty Kuvassa 3.

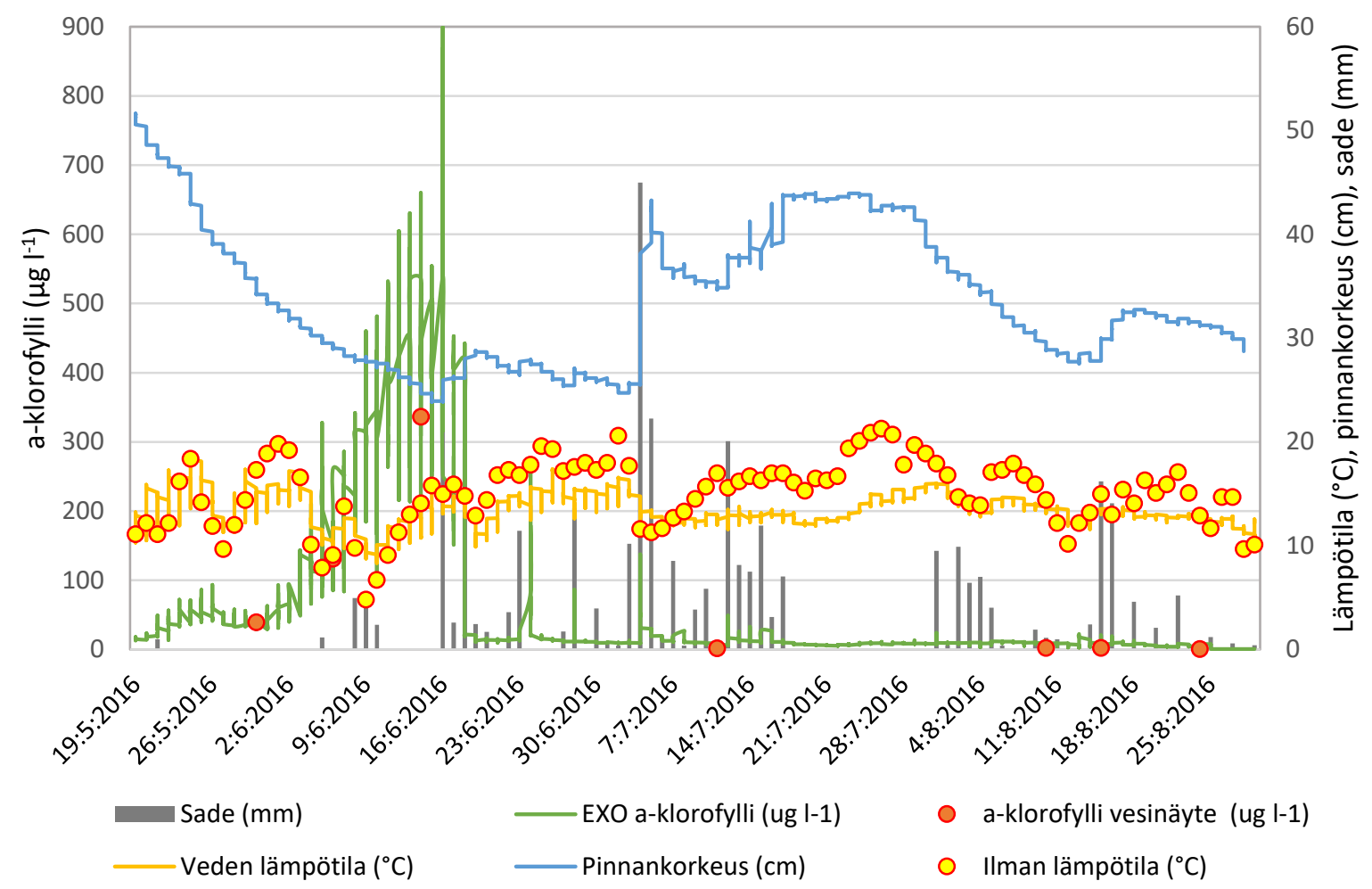

Kuva 3. Tutkimuskohteen ilman keskilämpötila $\left({ }^{\circ} \mathrm{C}\right)$, veden lämpötila $\left({ }^{\circ} \mathrm{C}\right)$, veden pinnankorkeus $(\mathrm{cm})$, päivittäinen sadesumma $(\mathrm{mm})$ ja automaattianturin mittaama sekä laboratoriossa määritetty a-klorofyllipitoisuus $\left(\mu \mathrm{g} \mathrm{l^{-1 }}\right)$ tutkimusjaksolla

Tässä tutkimuksessa mitatut a-klorofyllipitoisuudet olivat huomattavan korkeita verrattuna esimerkiksi Kuhan (2016) havaintoihin kuudelta suomalaiselta järveltä, joissa a-klorofyllipitoisuus vaihteli välillä 1,4-20 $\mu \mathrm{g} \mathrm{l}^{-1}$. Tämä voi selittyä konsentroituneen kosteikkoveden tavallista järvivettä korkeammilla ravinnepitoisuuksilla, jotka olivat tutkimusjaksolla aikaisempien tutkimusten (mm. Siimekselä ym. 2013) mukaisia maatalousalueen valumavesille tyypillisiä (Taulukko 1). A-klorofylli-pitoisuuden ja veden typpi-, fosfori- tai DOC-pitoisuuden välillä ei kuitenkaan tässä tutkimuksessa havaittu tilastollisesti merkitsevää yhteyttä. Edellä mainittujen muuttujien vaihtelu tutkimusjaksolla on esitetty Kuvassa 4.

Taulukko 1. Automaattiantureilla mitatut keskiarvot sekä minimi ja maksimiarvot veden sameudelle (FTU), kiintoaine-, N-tot-, $\mathrm{NO}_{3}-\mathrm{N}$ - ja DOC-pitoisuudelle $\left(\mathrm{mg} \mathrm{l}^{-1}\right.$ ) sekä P-tot- ja a-klorofyllipitoisuudelle ( $\mu \mathrm{l}^{-1}$ ) tutkimusjaksolla

\begin{tabular}{llllllll}
\hline & $\begin{array}{l}\text { Sameus } \\
\text { FTU }\end{array}$ & $\begin{array}{l}\text { Kiintoaine } \\
\mathrm{mg} \mathrm{l}^{-1}\end{array}$ & $\begin{array}{l}\text { P-tot } \\
\mu \mathrm{g} \mathrm{l}^{-1}\end{array}$ & $\begin{array}{l}\mathrm{N} \text {-tot } \\
\mathrm{mg} \mathrm{l}^{-1}\end{array}$ & $\begin{array}{l}\mathrm{NO}_{3}-\mathrm{N} \\
\mathrm{mg} \mathrm{l}^{-1}\end{array}$ & $\begin{array}{l}\text { DOC } \\
\mathrm{mg} \mathrm{l}^{-1}\end{array}$ & $\begin{array}{l}\text { a-klorof. } \\
\mu g ~ l^{-1}\end{array}$ \\
\cline { 2 - 7 } keskipit. & 7.7 & 15.9 & 221 & 2,2 & 1.4 & 21.2 & 59 \\
$\min$ & $<1$ & $<1$ & $<1$ & 1 & $<1$ & 10 & $<1$ \\
$\max$ & 57 & 124 & 1338 & 15 & 15 & 91 & 899 \\
\hline
\end{tabular}




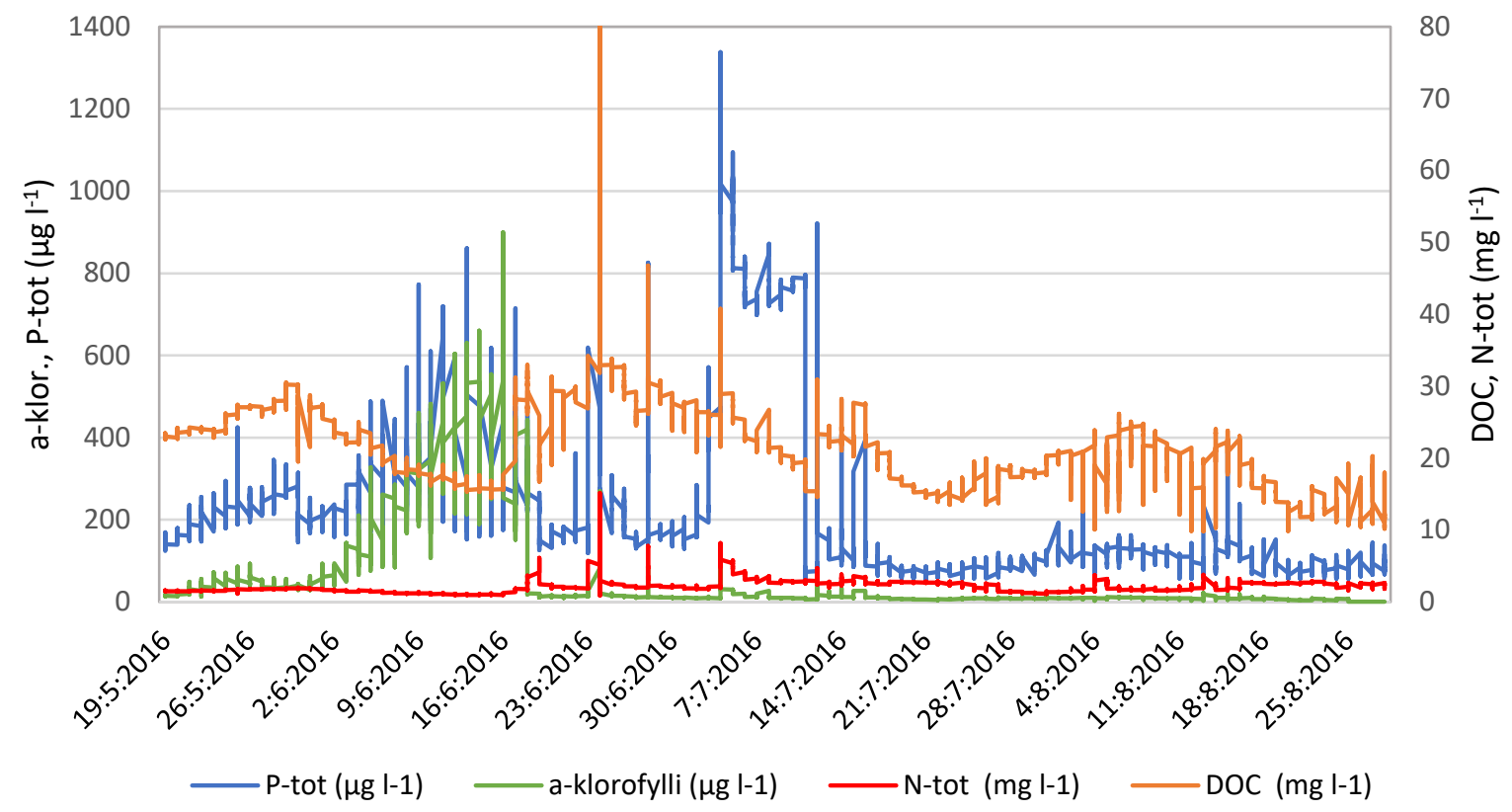

Kuva 4. Kokonaisfosfori- ja a-klorofyllipitoisuudet $\left(\mu \mathrm{g}^{-1}\right)$ sekä kokonaistypen ja liukoisen orgaanisen hiilen pitoisuudet $\left(\mathrm{mg} \mathrm{l}^{-1}\right)$ tutkimusjaksolla

\section{Johtopäätökset}

Jatkuvatoimiset in situ-mittauslaitteiden (EXO2 ja S::can) mittaamat tulokset vastasivat vesinäytteiden perusteella määritettyjä laboratorioarvoja tässä tutkimuksessa parhaimmillaan erinomaisesti. S::can anturin optisesti mittaamista muuttujista sameusarvot (FTU) vastasivat erinomaisesti laboratoriossa määritettyjä arvoja, kun taas kokonais- (N-tot) ja nitraattitypen $\left(\mathrm{NO}_{3}-\mathrm{N}\right)$ sekä liukoisen orgaanisen hiilen (DOC) osalta anturin mittaamien ja laboratoriossa määritettyjen pitoisuuksien selitysasteet olivat tyydyttäviä. Automaatti- ja laboratoriotulokset olivat kautta linjan numeerisesti hyvin lähellä toisiaan.

Tässä tutkimuksessa mielenkiinto mittaustekniikan toimivuuden sekä tulosten luotettavuuden osalta kohdistui pääasiassa EXO2-mittaussondin Total Algae-yhdistelmäanturin toimintaan, jolla tämän tutkimusten tulosten perusteella voitiin mitata luotettavasti veden leväpitoisuutta tutkimuskohteessa. Automaattianturilla mitatut a-klorofyllipitoisuudet vastasivat laboratoriossa määritettyjä pitoisuuksia erinomaisesti selitysasteen ollessa lähes $100 \%$.

A-klorofyllitulosten kalibroinnissa käytettiin selittävinä muuttujina anturin mittaaman a-klorofyllipitoisuuden lisäksi anturin mittaamaa fykosyaniinipitoisuutta. Veden lämpötilan tai liuennutta orgaanista ainesta (humusta) kuvaavan fDOM:n lisääminen yhtälöön ei parantanut kalibroinnin laatua. Vedessä olevilla humusaineilla ei tässä tutkimuksessa havaittu olevan vaikutusta a-klorofyllin mittaustuloksiin. Tulos on yhteneväinen Kringin ym. (2014) havaintojen kanssa. Orgaanisen aineksen häiritsevästä vaikutuksesta a-klorofyllimittaukseen on kuitenkin raportoitu useassa tutkimuksessa (mm. Leppä ym. 1995, Proctor ym. 2010, Goldman ym. 2013, Kuha 2016), joten orgaanisen aineen määrän mittaaminen aklorofyllimittausten yhteydessä sekä kyseisten arvojen käyttäminen parantamaan a-klorofyllin mittaustulosten kalibroinnin luotettavuutta on useissa tapauksissa perusteltua.

Tutkimuskohteen veden typpi- ja fosforipitoisuudet vastasivat tutkimusjaksolla maatalousalueen valumavesille tyypillisiä arvoja ja olivat niin ollen tavallisiin järvivesiin verrattuna huomattavan korkeat. Myös tutkimuskohteen veden a-klorofyllipitoisuus oli keskimäärin huomattavasti suurempi kuin järvivesissä yleensä tavataan. Kasviplanktonin määrän tiedetään lisääntyvän voimakkaasti vesistöön tulevan ulkoisen ravinnekuormituksen seurauksena, joten tutkimuskohteen veden suuri a-klorofyllipitoisuus oli todennäköisesti seurausta ravinteiden runsaudesta. Tätä tukee myös, että A-klorofyllipitoisuus vaikutti 
tutkimusjakson alkupuolella kesäkuun alusta kesäkuun puoleen väliin vaihtelevan veden fosforipitoisuuden vaihtelun mukaan. Myöhemmin tutkimusjaksolla ei enää havaittu samaa ilmiötä eikä tutkimuskohteen veden ravinne- ja a-klorofyllipitoisuuksien välille tässä tutkimuksessa löydetty tilastollisesti merkitsevää yhteyttä. Tämä voi selittyä esimerkiksi leväbiomassan luonnollisella vuotuisella vaihtelulla sekä tutkimusjakson edetessä erilaisten vesikasvien voimakkaalla runsastumisella, mikä ajoittui samaan aikaan veden a-klorofyllipitoisuuden ts. levämäärän vähenemisen kanssa. Koska vesikasvien määrää ei tässä tutkimuksessa tutkittu, tilastollista merkitsevyyttä kasvien runsastumisen ja levien katoamisen välille ei voitu löytää. On kuitenkin todennäköistä, että nopeasti kasvava tiheä kasvillisuus edesauttoi levien määrän vähenemistä kilpailemalla samoista ravinteista ja varjostamalla runsaasti valoa kasvuunsa tarvitsevia leviä.

Tämän tutkimuksen tulosten perusteella veden leväpitoisuutta ja sen vaihtelua voidaan mitata tutkimuskohteena olleella maatalouden vesiensuojelukosteikolla luotettavasti jatkuvatoimisella a-klorofyllin ja fykosyaniinin fluoresenssin mittauslaitteistolla. Jatkuvatoimisella mittauksella saatiin tarkkaa, reaaliaikaista tietoa levien määrästä ja määrän vaihtelusta tutkimuskohteella. A-klorofyllin fluoresenssin mittaamiseen voivat vaikuttaa lukuisat ympäristötekijät, jotka tulee tiedostaa ja huomioida mittausten aikana sekä mittaustulosten käsittelyssä ja analysoinnissa.

\section{Kirjallisuus}

Goldman E.A., Smith E.M. \& Richardson T.L. 2013. Estimation of chromophoric dissolved organic matter (CDOM) and photosynthetic activity of estuarine phytoplankton using multiple-fixed-wavelength spectral fuorometer. Water Research 47: 1616-1630.

Kring, S., Figary, S., Boyer, G., Watson, S. \& Twiss, M. 2014. Rapid in situ measures of phytoplankton communities using the bbe FluoroProbe: evaluation of spectral calibration, instrument intercompatibility, and performance range. Canadian Journal of Fisheries and Aquatic Sciences 71: 1087-1095.

Kuha, J. 2016. Automated Water Quality Monitoring of Humic Lakes by Using the Optical Properties of Water. Studies in Biological and Environmental Science 319. Jyväskylä: University of Jyväskylä. 39 p.

Leppä M., Karjalainen J. \& Holopainen A.-L. 1995. In vivo-fluorescence and Chlorophyll a determination in Finnish humic lakes. Aqua Fennica 25: 32-38.

Proctor C.W. \& Roesler C.S. 2010. New insights on obtaining phytoplankton concentration and composition from in situ multispectral Chlorophyll fluorescence. Limnology and Oceanography: Methods 8: 695-708.

Räty, M., Järvenranta, K., Virkajärvi, P., Saarijärvi, E. \& Kröger, H. 2014. Jatkuvatoiminen ravinnekuormituksen seurantaverkosto Kirmanjärven valuma-alueella. Julkaisussa: Hakojärvi, M. \& Schulman, N. (toim.). Maataloustieteen Päivät 2014. Suomen Maataloustieteellisen Seuran julkaisuja 30.

Siimekselä, T., Stenman, T. \& Ylimartimo, A. 2011. Tuloksia pilottikokeesta pienellä valuma-alueella Saarijärven vesireitin varrella. Vesitalous 52: 24-28.

Siimekselä, T., Ylimartimo, A., Stenman, T. \& Lahtela, S. 2013. Tuloksia vesistö-kuormituksesta peltovaltaisilla alueilla Keski-Suomessa. Vesitalous 54: 23-28.

Valkama, P., Lahti, K. \& Särkelä, A. 2007. Automaattinen veden laadun seuranta Lepsämänjoella. Terra 119: 195-206. 